International Journal of Advanced Chemistry, $9(1)(2021) 61-64$
International Journal of Advanced Chemistry
WPC
Website: www.sciencepubco.com/index.php/IJET
Research paper

\title{
Assessment of heavy metals in soil mining areas of gwanaalkaleri lga bauchi state
}

\author{
Mikin Siman ${ }^{1 *}$, Muhammed Abdulahi Shibdawa ${ }^{1}$, Harami Malgwi Adamu ${ }^{1}$, Zakaria Lakusha ${ }^{1}$, \\ Lungfa Collins Wuyep ${ }^{1}$, Maxwell Gudam Talkat ${ }^{1}$, Williams Nashuka Kaigama ${ }^{2}$ \\ ${ }^{1}$ Department of Chemistry, Faculty of Science, Abubakar Tafawa Balewa University, Bauchi; Nigeria \\ ${ }^{2}$ Department of Chemistry, Faculty of Physical Science, Ahmadu Bello University, Zaria, Nigeria \\ *Corresponding author E-mail: simanmikin@gmail.com
}

\begin{abstract}
Analysis of soil were carried out on mining areas and adjourning farmlands around Gwana in Alkaleri Local Government Area of Bauchi State. The physico-chemical analysis conducted includes $\mathrm{pH}$, electrical conductivity and moisture content which was accompanied by the geochemical characterization and quantification of the metal ions present in the soil. The $\mathrm{pH}$ of the soil was within the ranges from $5.6 \pm 0.01-6.7 \pm 0.01$, electrical conductivity was within the ranges of $185-290 \mathrm{mS} / \mathrm{cm}$ and percentage moisture content was within the ranges from $0.42-3.30$. the geochemical characterization revealed the presences of chromium $(11 \pm 0.02 \mathrm{mg} / \mathrm{Kg}), \mathrm{cobalt}(0.1-2.1 \mathrm{mg} / \mathrm{Kg})$, copper $(21.9 \pm 0.01-92.5 \pm 0.01 \mathrm{mg} / \mathrm{Kg})$, iron $(48 \pm 0.01-174 \pm 0.01 \mathrm{mg} / \mathrm{Kg})$, lead $(7.9 \pm 0.01-215 \pm 0.01 \mathrm{mg} / \mathrm{Kg})$, manganese $(19.8-164.8$ $\mathrm{mg} / \mathrm{Kg})$, nickel $(2.9 \pm 0.01-3.4 \pm 0.01 \mathrm{mg} / \mathrm{Kg})$, silver $(0.4 \pm 0.01-2.1 \pm 0.01 \mathrm{mg} / \mathrm{Kg})$ and zinc $(299 \pm 0.01-417 \pm 0.01 \mathrm{mg} / \mathrm{Kg})$. The concentration of metal ions of copper, lead and zinc in the soil samples collected from the study area revealed that they were excessively above their permissible limit set by the WHO, both in the areas of active mining operations and in the adjourning farmland. Hence the conclusion that the soils where contaminated as a result of the mining activities being carried out within the locality. Based on the high levels of these metal ions in the soils analyzed from the study area, it is hereby recommended that crop samples from within the catchment areas understudy should also be analyzed to evaluate their bioaccumulation coefficient, mobility index and their potential health risk index if any, that may arise from their being exposed to mining activity within the area.
\end{abstract}

Keywords: Physio-Chemical; Geochemical.

\section{Introduction}

Globally, there is a growing increase in the volume of mining activities, leading to high level of pollution as well as the introduction of other chemical compounds into the environment (Shrivr and Atkins, 1999). Mining of solid minerals has been identified as a major entry point of heavy metals into the environment consequently polluting various components of the environment such as soil, water and air (Tsafe et al., 2012). Opencast and underground mines are the commonly adopted methods of extraction of minerals from the earth, especially in developing countries like Nigeria (Ezen et al., 2011). Even after closure, these mines still pose environmental hazards by contaminating air, water and soil sediments from the scattered tailings, as well as pollution of underground water by discharged leachate, unless proper remediation is conducted (Tsafe et al., 2012). Mining activities have been going on in northern Nigeria since the colonial era, in places like Jos, and in late seventies in Zamfara mining belt (Alhassan et al., 2010).

Gwana, Alkaleri local government area, Bauchi state is also known for mining. Therefore, there is a need to assess the level of these contaminants within the area. There seemed to be a problem of environmental alteration, ecosystem and agricultural land destruction which prompted the researcher to investigate the depth of these environmental impacts.

\section{Materials and methods}

The sample area was around the mining area of Gwana District area, Alkaleri Local Government Area, Bauchi State, Nigeria located 74 $\mathrm{km}$ East of Bauchi town at latitude $9.8653458 \mathrm{~N}$ and longitude $10.8802486 \mathrm{E}$. The soil samples were collected by the random sampling method. Soil samples of $1 \mathrm{~kg}$ was collected from a depth of $0-15 \mathrm{~cm}$ from the mining pit, surface, adjourning farmland and a control area where no mining is done. The composite soil samples were oven dried to constant weights. The samples were then pulverized and passed through a $2 \mathrm{~mm}$ size sieve. The homogenized soil samples were stored in clean and dry containers subsequent to their digestion. About $1 \mathrm{~g}$ of the sample was digested using the triacid mixture of concentrated nitric acid $\left(\mathrm{HNO}_{3}\right)$, sulphuric acid $\left(\mathrm{H}_{2} \mathrm{SO}_{4}\right)$ and perchloric acid $\left(\mathrm{HClO}_{4}\right)$ in 5:1:1 ratio as described by Ademorati, 1996). The heavy metal concentrations in the digest were determined at the Center for Energy Research and Development, Abubakar Tafawa Balewa University Bauchi, using the Atomic Absorption Spectrophotometer. All the reagents were of analytical grade and were used as purchased. 
Soil $\mathrm{pH}$ and Electrical Conductivity were determined using a Jenway $3650 \mathrm{pH}$ meter. The moisture content of soil was determined by the method described by Angeloni et al. (2006).

\section{Results and discussion}

The results obtained from the physico-chemical characterization of soils samples taken from locations associated with mining activities around Gwana in Alkaleri Local Government Area of Bauchi State are resented in Table 1 below.

Table 1: Physico-Chemical Parameter of Soils Sampled at Mining Sites in Gwana, Alkaleri

\begin{tabular}{|c|c|c|c|c|}
\hline Parameter & Mine pit & Surface soil & Adjourning Farmland & Control \\
\hline $\mathrm{pH}$ & 6.7 & 6.4 & 6.2 & 5.6 \\
\hline Electrical conductivity $(\mathrm{mS} / \mathrm{cm})$ & 290 & 223 & 225 & 185 \\
\hline Moisture content (\%) & 3.30 & 0.42 & 2.80 & 1.92 \\
\hline
\end{tabular}

Results of the Physico-chemical parameter shows the $\mathrm{pH}$ measurements of the soils that where sampled to range from 5.6 - 6.7, Electrical conductivity to range from $185-290 \mathrm{mS} / \mathrm{cm}$ and moisture content to range from $0.42-3.30 \%$.According to De Matos et al., (2001) the $\mathrm{pH}$ and $\mathrm{EC}$ are vital geochemical soil parameter, with which important information can be deduced in other to understand the capacity of a soil type to retain heavy metal pollutants. Alkorta et al, (2004) had observed that soil pH is considered one of the most important factors determining the concentration of metals in the soil solution (moisture), their mobility and bioavailability.

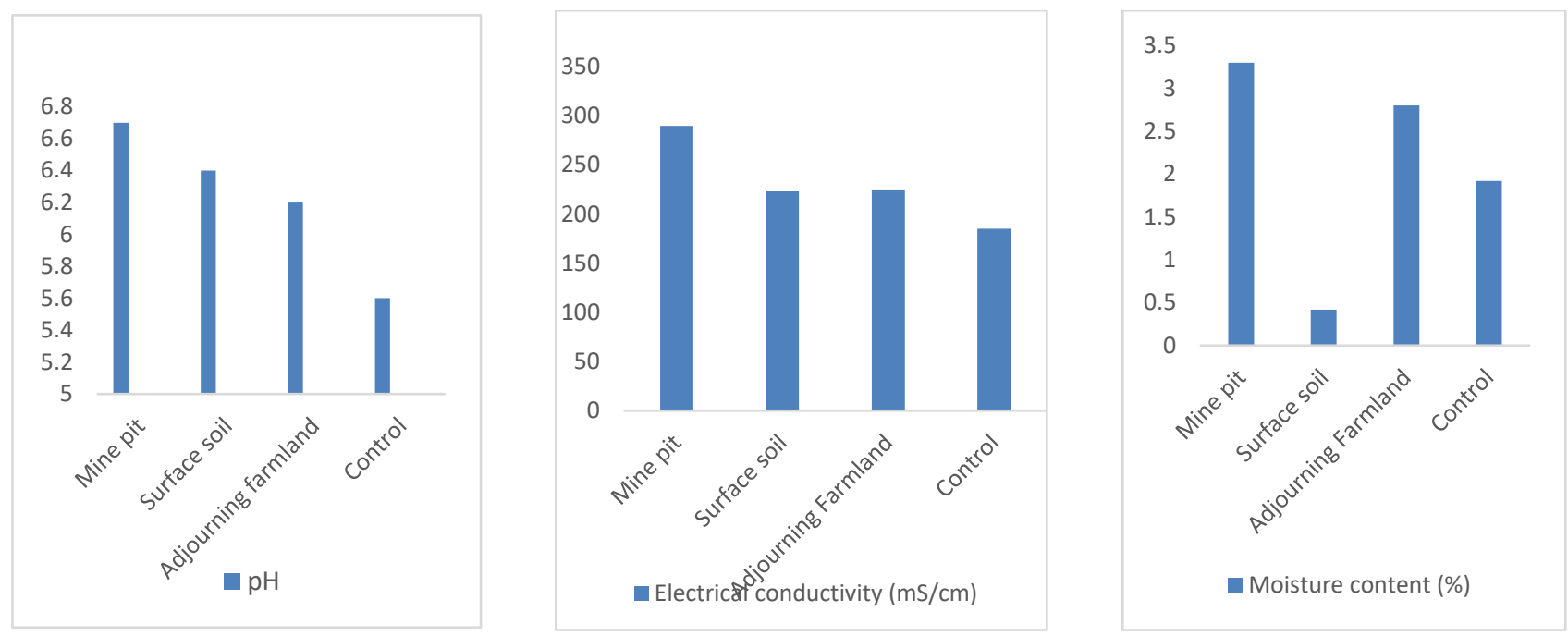

Fig. 1: Physico-Chemical Parameter of Soils Sampled at Mining Sites in Gwana, Alkaleri.

The Geochemical composition of the soil samples collected at mining sites in Gwana, Alkaleri. Revealed the presence of copper, iron, manganese, nickel lead, chromium, cobalt, silver and zinc in all the locations, while the presence of Lead was high in the mining site. The concentrations of these heavy metals contained in soils sampled at mining sites and its environs are presented in Table 2

Table 2: Geochemical Compositions of Soils Sampled at Mining Sites in Gwana, Alkaleri

\begin{tabular}{lcccc}
\hline & Mining site & Surface soil & Farmland & Control \\
\hline $\mathrm{Cu}$ & $92.5 \pm 0.02$ & $65.1 \pm 0.13$ & $56.7 \pm 0.02$ & $21.9 \pm 0.03$ \\
$\mathrm{Fe}$ & $174.0 \pm 0.01$ & $147.0 \pm 0.04$ & $49.0 \pm 0.00$ & $48.0 \pm 0.04$ \\
$\mathrm{Mn}$ & $164.8 \pm 0.01$ & $95.6 \pm 0.01$ & $24.0 \pm 0.01$ & $19.8 \pm 0.00$ \\
$\mathrm{Ni}$ & $2.9 \pm 0.00$ & $2.9 \pm 0.00$ & $2.7 \pm 0.00$ & $3.4 \pm 0.00$ \\
$\mathrm{~Pb}$ & $215.0 \pm 0.02$ & $92.7 \pm 2.00$ & $31.9 \pm 0.03$ & $7.9 \pm 0.02$ \\
\hline
\end{tabular}

The copper content ranged from $21.9 \mathrm{mg} / \mathrm{Kg}$ to $92.5 \mathrm{mg} / \mathrm{Kg}$. The lowest values of $21.9 \mathrm{mg} / \mathrm{kg}$ was of the samples taken at the control site and the highest value of $92.5 \mathrm{mg} / \mathrm{kg}$ was of those taken from the mining pit. Sanusi etal., (2017) have noted that copper has a permissible limit of $98.6 \mathrm{mg} / \mathrm{Kg}$, following this criterion it is observed that the concentration of copper in all locations were below the permissible limit. However, citing Alloway (1995), Alshaebi et al, (2009), noting that any soil having a copper concentration greater than $20 \mathrm{mg} / \mathrm{kg}$, it is considered contaminated soil, which implies that the results of the analysis carried out in the study area points to copper contamination in all the location. The comparative lower level of copper in the soils taken from the adjourning farmland and control site can be attributed to its low level of mobility of the copper ins within the soil (Wuana and Okieiman, 2011). This is a fact that Ezeh and Chukwu, (2012) have established and attributed to the non-easily dispersal of the ions from the spot from which it is being released. Though copper is an important micronutrient for plant (Thomas et al., 1998), it is only essential at low concentration and hazardous to plants, animals and human at excessive level. According to Zarie et al. (2011), high ingestion of copper leads to liver and kidney damage. It slows down the growth of plants and causes leaf chlorosis (Lewis et al., 2001). Therefore the area is not affected by both current and old mining activities in respect of copper. Copper is an essential micronutrient in living organism with well define role in body metabolism, though at elevated concentration could tend to be toxic. Copper is adsorbed to a greater extend by soils and soil constituents than most other heavy metals with the exception of lead (Ogabiela et al., 2010).

The concentration of iron in the area ranges from $48 \mathrm{mg} / \mathrm{Kg}$ to $174 \mathrm{mg} / \mathrm{Kg}$. all of which were well within the allowed permissible limit of $250 \mathrm{mg} / \mathrm{Kg}$ earlier cited by Fordyce et al., (2000). While these concentration of iron where out overtly high, Aubert and Pinta, (1977) have noted that their concentration was typical of the levels of iron content found in soil samples of tropical climate zones which is attributed to them been ferralitic in nature. 
The manganese content ranged from $19.8 \mathrm{mg} / \mathrm{Kg}$ to $164.8 \mathrm{mg} / \mathrm{Kg}$, of which Fordyce et al., (2000) have cited its permissible limit to be 50 $\mathrm{mg} / \mathrm{Kg}$. Of the soils samples being studied it was noted that the concentration of manganese at the mining pit and the soil surface were above this limit. Though, manganese is an essential micronutrients, Reeves and Baker, (2000) have however pointed out that in excess it becomes toxic to plant, a fact which have been buttressed by Blaylock and Huang, (2000) and Boadu et al., (2000) of it reported effect on Worthy of note is the fact that manganese has low solubility at neutral and alkaline $\mathrm{pH}$ which assist in preventing its excessive uptake by plants. Hence, its toxicity is usually associated with acidic soils (Eze and Ekanem, 2014).

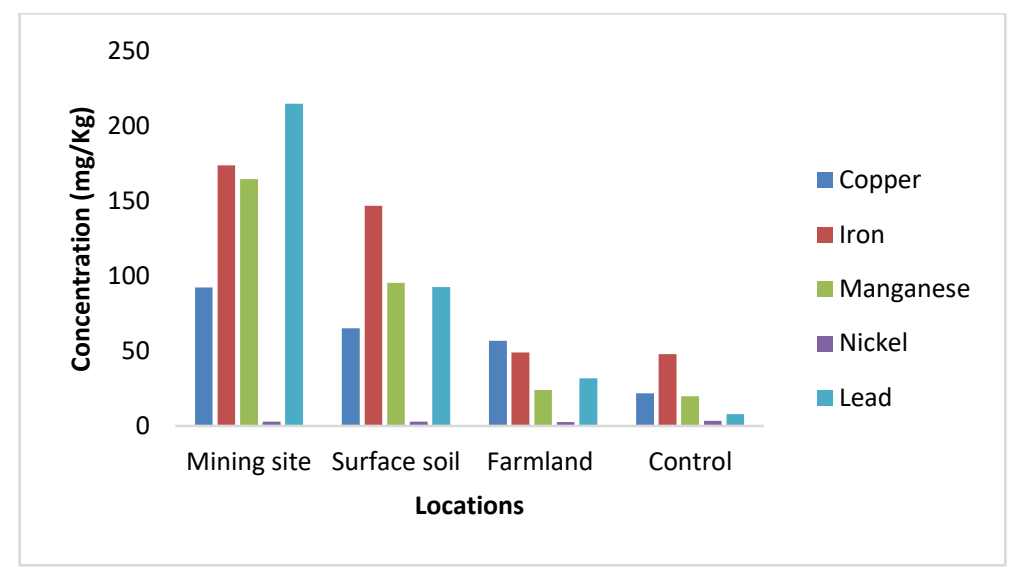

Fig. 2: Geochemical Compositions of Soils Sampled at Mining Sites in Gwana, Alkaleri.

The nickel content ranged from $2.9 \mathrm{mg} / \mathrm{Kg}$ to $3.4 \mathrm{mg} / \mathrm{Kg}$. According to Rana (2006) the permissible limit of nickel is $40 \mathrm{mg} / \mathrm{kg}$. hence this result shows that the soil is not contaminated by nickel. According to Gimemo-Garcia et al. (1996), apart from human activities such as mining, that introduces nickel into the environment, factors such as acid rain facilitates it transportation and accumulation in both soil and ground water. Yaron (1996) have pointed out that nickel ions are mostly concentrated in the top soil, especially those rich in organic matter or with relatively high content of clay. Hence, it relatively higher concentration in the control soil samples confirms that assertion and is also similar to what has being reported by Akko et al., (2014). Nickel is a poisonous heavy metal, Rahman et al., (2005) have pointed out that high concentration of nickel is known to cause chlorosis in plants and in human, it leads to respiratory and skin disorder. Yaron (1996), also noted that wide application of various types of pesticides and fertilizer may be contributor to the increased in availability of nickel in the

The lead content ranged from $7.9 \mathrm{mg} / \mathrm{Kg}$ to $215.0 \mathrm{mg} / \mathrm{Kg}$. Of these values obtained from the study areas the concentration of lead ion in the mining pit was above the maximum permissible level of $100 \mathrm{mg} / \mathrm{kg}$, and that at the surface was barely lower than the limit (Eze and Ekanem 2014). However, according to Niragu (1978) the soil is considered uncontaminated when its concentration is more than 20 $\mathrm{mg} / \mathrm{kg}$. Sanusi et al. (2017), have pointed out that carbonate enhances the retention of Lead in soils surrounding mining areas, hence the seemingly high levels of lead in the control area could be attributed to it presence. Osher et al. (2006) reported that elements such as lead is transported in water, food and soil. It gets accumulated in plants and animals and passed across the food chain to human. Ling et al. (2006), reported that it causes brain and kidney problem in human. Nagajyoti et al., (2010). High content of lead in plant is detrimental to its morphology, growth and photosynthetic processes.

\section{Conclusions}

The concentration of metal ions of copper, lead and zinc in the soil samples collected from the study area revealed that they were excessively above their permissible limit, both in the areas of active mining operations and in the adjourning farmland. Hence the conclusion that the soils where contaminated as a result of the mining activities being carried out within the locality. Based on the high levels of these metal ions in the soils analyzed from the study area, it is hereby recommended that crop samples from within the catchment areas understudy should also be analyzed to evaluate their bioaccumulation coefficient, mobility index and their potential health risk index if any, that may arise from their being exposed to mining activity within the area.

\section{References}

[1] Ako T. A., Onoduku U. S., Oke S. A., Adamu I. A., Ali S. E., Mamodu A., Ibrahim A. T. (2014) "Environmental Impact of Artisanal Gold Mining in Luku, Minna, Niger State, North Central Nigeria" Journal of Geosciences and Geomatics, 2, (1): 28-37

[2] Alkorta I., Hernandez-Alica J., Becerril J.M., Amezaga I., Albizu I., Garbisu C., Recent Findings On The Phytoremediation Of Soils Contaminated With Environmentally Toxic Heavy Metals And Metalloids Such As Zinc, Cadmium, Lead And Arsenic, Reviews in Environmental Science and Bio/Technology 2004, 3, 71-90. https://doi.org/10.1023/B:RESB.0000040059.70899.3d.

[3] Alloway B.J., Ayres D.C., (1997). Chemical Principles of Environmental Pollution, 2nd ed Blackie Academic and Professional Chapman and Hall, London, pp.190-242.

[4] Blaylock, M. J. and Huang, J. W. (2000) Phytoextraction of metals. In: Raskin I, Ensley BD (eds) Phytoremidation of toxic metals-using plants to clean up the environment. Wiley, New York, pp 53-70,

[5] Boadu, M., Osae, E. K. Golow, A. A. Serfor-Armah, Y. and Nyarko, B.J. B. Determination of arsenic in some water bodies, untreated ore and tailing samples at Konongo in the Ashanti region of Ghana and its surrounding towns and villages by instrumental neutron activation analysis. Journal of Radioanalytical Nuclear. Chemistry 249: 581-585, 2000.

[6] De Matos AT, Fontes MPF, Da Costa LM, Martínez MA (2001). Mobility of heavy metals as related to soil chemical and mineralogical characteristics of Brazilian soils. Environ. Pollut. 111:429-35. https://doi.org/10.1016/S0269-7491(00)00088-9.

[7] Eze, M. O. and Ekanem, E. O.(2014) Bioaccumulation and Mobility of Cadmium (Cd), Lead (Pb) and Zinc ( $\mathrm{Zn}$ ) in Green Spinach Grown on Dumpsite Soils of Different pH Levels Bulletin of Environment, Pharmacology and Life Sciences 4 (1) December: 85-91

[8] Fordyce, F. M. Guangdi, Z. Green K. and Xinping, Soil, grain and water chemistry in relation to human selenium-responsive diseases in Enshi district, China. Applied Geochem. 15: https://doi.org/10.1016/S0883-2927(99)00035-9. 
[9] Gimeno-Garcia, E., Andreu, V. and Boluda, R. Heavy metals incidence in the application of inorganic fertilizers and pesticides to rice farming soils. Environ Pollu 92: 19-25, 1996. https://doi.org/10.1016/0269-7491(95)00090-9.

[10] Lewis, S., Donkin, M. E. and Depledge, M. H. Hsp 70 expression in Enteromorpha intestinalism (Chlorophyta) exposed to environmental stressors. Aqua Toxicol. 51, 277-291, 2001. https://doi.org/10.1016/S0166-445X(00)00119-3.

[11] Ling, C., Ching-ying, Y., Hung-Chang, L., Hsing-Jasine, C., Ming-Jers and Bor- Cheng, H. Effect of mother's consumption of traditional Chinese herbs on estimated infant daily intake of lead from breast milk. Sci. Total Environ., 354, 120-126, 2006 https://doi.org/10.1016/j.scitotenv.2005.01.033.

[12] Nagajyoti, P. C., Lee, K. D. and Sreekanth T. V. M. Heavy metals, occurrence and toxicity for plants Environ: a review. Chem Lett., 8: 199-216, 2010. https://doi.org/10.1007/s10311-010-0297-8.

[13] Shrivr, D. F. and Atkins, P. W, (1999). Inorganic Chemistry, 3rd edn. Oxford University Press ISBN pp. 0-19-850330-X.

[14] Sanusi, K. A. Mohammed S. Hassan, Muazu A. Abbas and Aishatu M. Kura (2017) "Assessment of heavy metals contamination of soil and water around abandoned $\mathrm{Pb}-\mathrm{Zn}$ mines in Yelu, Alkaleri Local Government Area of Bauchi State, Nigeria" International Research Journal of Public and Environmental Health 4(5):72-77

[15] Ezeh HN, Chukwu E, (2011). Small scale mining and heavy metals pollution of agricultural soil. Nig. J. Geol. Mining Res. 3(4): 87-104

[16] Tsafe AI, Hassan LG, Sahabi DM, Alhassan Y, Bala, BM (2012). Evaluation of Heavy Metals Uptake and Risk Assessment of Vegetables Grown in Yargalma of Northern Nigeria. J. Basic and Appl. Sci. Res. 2(12): 6708-6714.

[17] Wuana RA, Okieimen FE (2011). Heavy Metals in Contaminated Soils: A Review of Sources, Chemistry, Risks and Available Strategies for Remediation. Int. J. Sci. Ecotoxicol. Res. 2(10): 100-106. https://doi.org/10.5402/2011/402647.

[18] Nagajyoti, P. C., Lee, K. D. and Sreekanth T. V. M. Heavy metals, occurrence and toxicity for plants Environ: a review. Chem Lett., 8: 199-216, 2010. https://doi.org/10.1007/s10311-010-0297-8.

[19] Osher, L. J., Leclerc, L., Wiersma, G. B., Hess, C.T. and Guiseppe, V. E. Heavy metal contamination from historic mining in upland soil and estuarine sediments of Egypt Bay, Maine, USA. Estuarine, Coastal and Shelf Science, 70 (1-2), 169-179, 2006. https://doi.org/10.1016/i.ecss.2006.06.009.

[20] Rahman, H., Sabreen, S., Alam, S. and Kawai, S. Effects of nickel on growth and composition of metal micronutrients in barley plants grown in nutrient solution. Jour. Plant Nutri 28:393-404, 2005. https://doi.org/10.1081/PLN-200049149.

[21] Reeves, R. D. and Baker, A. J. M. Metal-accumulating plants. In: Raskin, I. and Ensley, B. D. (eds) Phytoremediation of toxic metals: using plants to clean up the environment. Wiley, New York. pp 193-229, 2000. Journal of Geosciences and Geomatics 37

[22] Thomas F., Malick C., Endreszl, E. C. and Davies, K. S. Distinct responses to copper stress in the halophyte, Mesembryanthemum rystallium. Physiol Plant 102: 360-368, 1998. https://doi.org/10.1034/j.1399-3054.1998.1020304.x.

[23] Zarei, M., Eskandari, M. H. and Pakfetrat, S. Determination of heavy metals content of refined table salts. American-Eurasian Journal of Toxicological Sciences, 3 (2):59-62, 2011.

[24] Aubert, H. and Pinta, M. (1977). Trace elements in soils. Development in Soil Science No. 7.pp 395Elsevier Scientific Publishing company, Amsterdam.

[25] Ogabiela et al., (2010): Determination of the levels of some elements in Edible oils sold in Zaria, Northern Nigeria. Global Journals of Pure and Applied Sciences, vol.16 NO.3, 325-331. https://doi.org/10.4314/gjpas.v16i3.62860. 